\title{
Implementasi Kegiatan Pramuka \\ Dalam Membangun Karakter Kedisiplinan Siswa SD/MI
}

\author{
Mufarizuddin \\ Program Studi PGSD Fakultas Ilmu Pendidikan Universitas Pahlawan Tuanku Tambusai Riau \\ zuddin.unimed@gmail.com
}

\begin{abstract}
Discipline is an important key in an activity. One can not complete an activity with optimal results without discipline. Discipline is an attitude that requires a person to be responsible for his actions, obedient to the decisions and commandments, and accuracy in respecting the time. Discipline in a school is necessary to create order and order. Therefore, it was established school order. But lately the order began to decline function. This is because, the discipline that is formed is a discipline that is forced, not because of consciousness but because of fear of punishment. Therefore schools need to foster discipline among their students. Awareness enforcing discipline can be trained with positive activities held by schools through extracurricular. One of them is Scout activities. From this boy scout activities students will be accustomed to apply discipline in every activity held. So hopefully between scout and discipline activities have a close relationship.
\end{abstract}

Keyword: Scouting activities, Discipline Character

\section{PENDAHULUAN}

Pendidikan karakter dalam kurikulum 2013 bertujuan untuk meningkatkan mutu proses dan hasil pendidikan, yang mengarah pada pembentukan budi pekerti dan akhlak mulia peserta didik secara utuh, terpadu, dan seimbang sesuai dengan standar kompetensi lulusan pada setiap satuan pendidikan. Melalui impelementasi kurikulum 2013 yang berbasis kompetensi sekaligus berbasis karakter, dengan pendekatan tematik dan kontekstual diharapkan peserta didik mampu secara mandiri meningkatkan dan menggunakann pengetahuannya, mengkaji dan menginternalisasi serta mempersonalisasi nilainilai karakter dan akhlak mulia terwujud dalam kehidupan sehari-hari.

Masalah yang sedang dihadapi oleh bangsa Indonesia saat ini adalah sistem pendidikan yang ada sekarang terlalu berorientasi pada pengembangan otak kiri (kognitif) dan kurang memperhatikan pengembangan otak kanan (afektif, empati, dan rasa). Disadari atau tidak, bangsa Indonesia saat ini telah digiring untuk membentuk anak menjadi manusia- manusia instant yang sekali pakai dan tidak bertahan lama. Hal ini makin terasa menjelang akhir ujian nasional atau ujian akhir sekolah. Berdasarkan pada teori majemuk, potensi akademik hanyalah sebagian saja dari potensipotensi.
Untuk mengatasi hal tersebut perlu adanya kegiatan pembelajaran yang mengacu pada pengembangan karakter siswa. Salah satu bentuk pembelajaran tersebut adalah kegiatan ekstrakurikuler. Karena, pengembangan karakter lebih berkaitan dengan dengan optimalisasi fungsi otak kanan (afektif, empati, dan rasa). Banyak yang berpikir bahwa pendekatan pembelajaran sekarang ini cenderung kepada aspek kognitif (otak kiri), sehingga telah mengubah orientasi belajar para siswa menjadi semata-mata untuk meraih nilai tinggi. Oleh sebab itu perlu dilaksanakan reformasi pendidikan ke arah yang lebih kondusif untuk terciptanya kualitas SDM yang berkualitas, terutama melalui pengenalan konsep pendidikan holistik atau menyeluruh. Salah.

Salah satu kegiatan ekstrakurikuler yang dapat membentuk karakter siswa dan berorientasi pada otak kiri dan kanan adalah kegiatan Pramuka. Kegiatan pramuka tidaklah asing bagi warga Negara Indonesia, terutama bagi mereka yang berada di lingkungan pendidikan. Bahkan pramuka erat kaitanya dengan sejarah kemerdekaan Indonesia. Pramuka membangun akhlak anak bangsa yang baik. Melalui pendidikan pramuka ini dapat dilakukan pembinaan ketakwaan terhadap Tuhan Yang Maha Esa, kehidupan berbangsa dan bernegara berdasarkan Pancasila, pendidikan pendahuluan bela negara, 
kepribadian dan budi pekerti luhur, berorganisasi, pendidikan kewiraswastaan, kesegaran jasmani dan daya kreasi, persepsi, apresiasi dan kreasi seni, tenggang rasa dan kerjasama (Moh. Imam Mukhlis, 2016).

Pramuka adalah proses pendidikan di luar lingkungan sekolah dan di luar lingkungan keluarga, dalam bentuk kegiatan menarik, menyenangkan, sehat, teratur, terarah, praktis, yang dilakukan di alam terbuka dengan prinsip dasar kepramukaan dan metode kepramukaan. Sedangkan Gerakan Pramuka adalah Gerakan (Lembaga) Pendidikan yang komplementer dan suplementer (melengkapi dan memenuhi pendidikan yang diperoleh anak/remaja/pemuda di rumah dan di sekolah), pada segmen yang belum ditangani oleh lembaga pendidikan lain yang pelaksanaannya mengunakan prinsip dasar kepramukaan dan metode kepramukaan; di Alam Terbuka (outdoor activities), dan yang sekaligus dapat menjadi upaya "self education" bagi dan oleh anak/remaja/pemuda/pramuka sendiri.

Pramuka merupakan sebuah kegiatan organisasi pendidikan non formal yang memiliki konsep yang baik dan tersusun rapi. Selain itu, pramuka juga memberikan manfaat yang besar kepada anak baik secara langsung ataupun tidak langsung. Tidak heran lagi jika Pramuka sekarang digalakkan di sekolah dan dipandang sebagai kegiatan yang bagus bagi anak dan merupakan kebutuhan bagi anak di SD/MI. Kegiatan Pramuka tidak hanya mempelajari baris-berbaris dan kegiatan lainnya, Pramuka juga mempelajari tentang pendidikan dibidang keagamaan, teknologi, jasmani/kesehatan, alam sekitar, sosial, dan lain sebagainya. Karena kegiatan yang dilakukan Pramuka itu berhubungan langsung dengan masyarakat dan merupakan salah satu contoh dari pendidikan dibidang sosial, maka sangat bagus untuk membentuk karakter kepribadian pada anak. Salah satunya karakternya itu adalah karakter kedisiplinan.

Pasal 4 Undang-undang Nomor 12 Tahun 2010 berisi tentang Gerakan pramuka bertujuan untuk membentuk setiap pramuka agar memiliki kepribadian yang beriman, bertakwa, berakhlak mulia, berjiwa patriotik, taat hukum, disiplin, menjunjung tinggi nilainilai luhur bangsa, dan memiliki kecakapan hidup sebagai kader bangsa dalam menjaga dan membangun Negara Kesatuan Republik Indonesia, mengamalkan Pancasila, serta melestarikan lingkungan hidup.

Pemaparan diatas merupakan alasan penulis untuk mengambil judul ini, karena betapa pentingnya peran pramuka dalam membentuk karakteristik kedisiplinan anak di SD/MI. Sehingga anak bisa secara sadar untuk disiplin dalam segala kegiatan sehari-hari anak, baik kegiatan di sekolah maupun kegiatan di pramuka.

\section{KAJIAN PUSTAKA}

\section{Implementasi}

Menurut Nurudin Usman (2002:70): "Implementasi adalah bermuara pada aktivitas, aksi, tindakan, atau adanya mekanisme suatu system. Implementasi bukan sekedar aktivitas, tetapi suatu kegiatan yang terencana dan untuk mencapai tujuan kegiatan" 3. Jadi, maksud Implementasi adalah penelitian ini yaitu kegiatan pramuka yang mempunyai tujuan untuk membentuk karakter disiplin siswa.(Moh. Imam Mukhlis, 2016)

\section{Kegiatan Pramuka}

Salah satu kegiatan ekstrakurikuler yang dapat membentuk karakter siswa dan berorientasi pada otak kiri dan kanan adalah kegiatan Pramuka. Gerakan Pramuka adalah nama organisasi yang merupakan suatu wadah proses pendidikan kepramukaan yang ada di Indonesia. Tujuan gerakan Pramuka adalah terwujudnya kaum muda Indonesia menjadi manusia yang berwatak, berakhlak mulia, berkepribadian, memiliki kepedulian terhadap sesama hidup, dan PendidikanPramuka agar nantinya dapat berguna ketika hidup di masyarakat dan di alam.(Aji, 2016)

Kepramukaan mempunyai fungsi sebagai berikut .

a. Kegiatan menarik bagi anak dan pemuda (game)

Kegiatan menarik ini maksudnya adalah kegiatan yang menyenangkan tetapi mengandung pendidikan. Sedapat mungkin kegiatan pramuka dirancang dengan menarik. Karena pesertanya adalah usia anak-anak yang masih dalam taraf bermain maka akan lebih cocok jika kegiatannya diisi dengan permainan yang mendidik. Kegiatan permainan ini cocok untuk diterapkan pada pramuka usia siaga (710 tahun) dan pramuka usia penggalang (11-15 tahun).Kegiatan yang dilakukan antara lain : senam tongkat, senam semaphore, belajar mengirim berita melalui kata-kata sandi, belajar mengenal alam dengan mengajaknya jalan-jalan santai dan belajar menyanyi.

b. Pengabdian (job) bagi orang dewasa

Bagi orang dewasa pramuka bukan lagi bermain, melainkan suatu tugas yang 
memerlukan keikhlasan, kerelaan, dan pengabdian. Kewajibannya adalahdengan suka rela membaktikan dirinya demi suksesnya pencapaian tujuan organisasi. Biasanya kegiatan ini dilakukan oleh pramuka usia penegak (16-20 tahun) dan pramuka usia pandega (21-25 tahun) akan lebih cocok jika kegiatannya langsung diabdikan kepada masyarakat seperti : pengumpulan dan untuk membantu korban bencana, menjadi sukarelawan di daerah bencana dan lain-lain.

\section{c. Alat (means) bagi masyarakat dan organisasi Kepramukaan}

Kepramukaan merupakan alat untuk memenuhi kebutuhan masyarakatsetempat. Dan juga alat bagi organisasi untuk mencapai tujuan organisasinya. Masyarakat pada dasarnya menginginkan kehidupan yang aman, damai dan sejahtera. Untuk menciptakan kehidupan yang demikian diperlukan insan-insan yang tangguh secara lahir dan batin. Namun untuk menciptakan insan yang diharapkan tidak hanya cukup dengan pendidikan formal saja. Masyarakat masih membutuhkan peran lain di luar pendidikan formal. Salah satunya adalah dengan kegiatan kepramukaan. Karena dalam Anggaran Dasar Gerakan Pramuka pasal 4 dijelaskan tujuan gerakan pramuka yang salah satunya adalah membina dan mendidik kaum muda Indonesia agar dapat membangun dirinya secara mandiri serta bersama-sama bertanggung jawab atas pembangunan bangsa dan negara. Jadi kegiatan kepramukaan yang diberikan sebagai latihan berkala dalan satuan pramuka itu sekedar alat saja dan bukan tujuan pendidikannya. (Upik Isriyanah, 2007)

\section{Tujuan Kegiatan Pramuka}

Menurut Suryosubroto (2009:287) kegiatan ekstrakurikuler adalah kegiatan tambahan di luar struktur program yang dilaksanakan di luar jam pelajaran biasa agar memperkaya dan memperluas wawasan pengetahuan dan kemampuan siswa. Berdasarkan Undang-Undang Republik Indonesia Nomor 12 Tahun 2010 Tentang Gerakan Pramuka "Pramuka adalah warga negara Indonesia yang aktif dalam pendidikan kepramukaan serta mengamalkan Satya Pramuka dan Darma Pramuka". Berdasarkan pengertian dari poin-poin di atas dapat dijelaskan bahwa pengertian ekstrakurikuler pramuka adalahprogram atau kegiatan yang dikakukan di luar jam sekolah yang mengenalkan Satya Pramuka dan Darma Pramuka yang di bentuk untukmenyelenggarakan pendidikan karakter dan kemampuan siswa, diselenggrakan oleh pihak sekolah.(Tofiq Muctharjo, 2013)

Tujuan kegiatan pramuka mendidik dan membina kaum muda guna mengembangkan mental, sosial, moral, spiritual, emosional intelektual dan fisik sehingga menjadi manusia berkepribadian, berwatak dan berbudi pekerti luhur, menjadi warga negara Indonesia yang berjiwa Pancasila, menjadi anggota masyarakat yang baik dan berguna, yang dapat membangun dirinya sendiri secara mandiri serta bersama bertanggung jawab untuk bangsa dan negara, memiliki kepedulianterhadap sesama hidup dan alam, lingkungan baik lokal, nasional dan internasional.

\section{Disiplin}

Disiplin adalah kepatuhan untuk menghormati dan melaksanakan suatu sistem yang mengharuskan orang tunduk pada keputusan, perintah, atau peraturan yang diberlakukan bagi dirinya sendiri (Lemhannas, 1995:11). Misalnya senam pagi adalah salah satu disiplin pribadi. Kepatuhan seseorang terhadap keputusan, perintah, atau peraturan diberlakukan bagi suatu sistem dimana orang itu terlibat disebut disiplin perorangan. Disiplin perorangan menuntut orang yang bersangkutan bertanggung jawab atas pelaksanaan kepatuhan. Tanggung jawab atas perbuatannya dan pelaksanaan atas keputusan, perintah, atau peraturan dengan segala akibatnya terletak ditangan orang yang memberi perintah atau yang membuat keputusan dan perintah. Disiplin perorangan bersifat perorangan atau individual yaitu berkaitan dengan sifat yang langsung melekat pada diri seseorang.(Upik Isriyanah, 2007).

Menurut Mar'at (1984: 90) disiplin adalah sikap perseorangan atau kelompok yang menjamin adanya kepatuhan terhadap perintah-perintah yang berinisiatif untuk melakukan suatu tindakan yang perlu seandainya tidak ada perintah. Hal ini merupakan hasil latihan-latihan yang efektif dan kepemimpinan yang baik.

Jadi disiplin adalah kepatuhan untuk menghormati dan melaksanakan suatu sistem yang mengharuskan orang tunduk pada keputusan, perintah, atau peraturan yang diberlakukan bagi dirinya sendiri (Lemhannas, 1995:11). Misalnya senam pagi adalah salah satu disiplin pribadi. Kepatuhan seseorang terhadap keputusan, perintah, atau peraturan diberlakukan bagi suatu sistem dimana orang 
itu terlibat disebut disiplin perorangan. Disiplin perorangan menuntut orang yang bersangkutan bertanggung jawab atas pelaksanaan kepatuhan. Tanggung jawab atas perbuatannya dan pelaksanaan atas keputusan, perintah, atau peraturan dengan segala akibatnya terletak ditangan orang yang memberi perintah atau yang membuat keputusan dan perintah. Disiplin perorangan bersifat peroranganatau individual yaitu berkaitan dengan sifat yang langsung melekat pada diri seseorang.

\section{PEMBAHASAN}

Berdasarkan kajian singkat tentang impelemntasi kegiatan Pramuka dalam membangun karakter kedisiplinan Siswa $\mathrm{SD} / \mathrm{MI}$ diatas, selanjutnya penulis mencoba memberikan pembahasan dari Impelementasi Kegiatan Pramuka Dalam Membangun KarakterKedisiplinan Siswa SD/MIsebagai berikut.

Kegiatan ekstrakurikuler pramuka merupakan sarana yang tepat untuk membentuk dan mengembangkan karakter disiplin peserta didik. Kegiatan pramuka, mengajarkan anak untuk dapat tepat waktu dalam menjalankan aktivitasnya baik ketika berkemah atau kegiatan pramuka yang lainnya, tetapi anak juga dilatih untuk bisa tepat waktu dalam kegiatan sehari-hari diluar Pramuka. Tepat waktu disini adalah salah satu bentuk contoh kedisiplinan secara sederhana yang bisa diterapkan ke anak SD/MI. Jika anak sudah terbiasa melakukan segala aktivitas dengan tepat waktu, maka akan tumbuh jiwa kesadarannya tanpa disuruh untuk melaksanakan kegiatan tersebut.

Ketika penulis melakukan penelitian kecil dalam bentuk observasi di pada salah satu SD Bangkinang Kota, Kabupaten Kampar. Anak-anak mengikuti kegiatan ekstarkurikuler Pramuka pada pukul 16.00 WIB. Dan anakanak yang mengikuti kegiatan Pramuka tersebut, sudah mulai berdatangan pukul 15.30 dan memang ada yang datang terlambat. Ketika anak tersebut datang terlambat dengan kesadaran anak tersebut melaksanakan hukuman lari keliling lapangan sebanyak 3 kali. Hukuman yang diberikan oleh Pembina Pramuka itu semata-mata untuk melatih kedisiplinan anak dan membiasakan anak untuk datang tepat waktu. Dalam kegiatan ekstrakurikuler pramuka di SD Bangkinang Kota, Kabupaten Kampar, anak-anak diajarkan berbagai kegiatan, misalnya barisberbaris dan membuat sebuah penyaring air.
Didalam kegiatan membuat sebuah penyaring air anak-anak diberikan waktu selama 10 menit untuk melakukan uji coba. Pemberian waktu uji coba selama 10 menit bertujuan melatih ketepatan waktu yang diberikan pembina. Apakah anak-anak bisa dan berhasil dalam uji coba penyaring air dalam waktu singkat. Setelah dibuktikan anak-anak berhasil melakukan uji coba yang dilaksanakan dengan hasil air kotor yang disaring menjadi air jernih. Keberhasilan mereka dengan waktu singkat itu karena ketepatan waktu dan ketelitian yang dimiliki. Ketika waktu ekstrakurikuler pramuka sudah akan berakhir maka anak-anak mengingatkan kepada Pembina agar kegiatan ekstrakurikuler pramuka segera diakhiri. Sebelum mengakhiri kegiatan ekstrakurikuler ini pembina memberikan arahan agar anakanak tetap disiplin baik di sekolah dan di luar sekolah agar bisa mendapat hasil yang maksimal dari apa yang mereka kerjakan.

Pada kesempatan ini penulis berkesempatan terjun langsung mengajar anak-anak. Dalam kesempatan kali ini materi yang disampaikan adalah disiplin berpakaian dalam pramuka. Pembina pramuka memberikan info bahwa anak-anak yang pramuka siaga dan pramuka penggalang dipisah. Pramuka siaga masuk kedalam kelas dan pramuka penggalangnya tetap di lapangan atau belajarnya di luar ruangan. Materi disiplin berpakaian dalam pramuka disampaikan pada pramuka siaga. Pada saat penyampaian materi anak-anak memperhatikan dengan seksama tentang apa disampaikan. Setelah selesai penyampaian materi penulis mencoba memberikan contoh seragam pramuka yang benar antara laki-laki dan perempuan dengan memanggil anak lakilaki dan perempuan sebagai contoh untuk teman-teman didepan kelas. Dan membuat penulis bangga dan takjub adalah anak-anak SD Bangkinang Kota seragam pramuka sudah lengkap dan sesuai standar yang berlaku. Hal tersebut membuktikan bahwa kedisiplinan berpakaian yang diterapkan dalam pramuka dapat melatih anak untuk berpakaian rapi dan bersih ketika menjalankan aktivita baik di sekolah dan di rumah.

\section{KESIMPULAN \& SARAN}

Dari hasil telaah dan pembahasan Impelementasi Kegiatan Pramuka dalam Membangun Karakter Kedisiplinan Siswa $\mathrm{SD} / \mathrm{MI}$ dapat penulis simpulkan antara lain, sebagai berikut :

1. Kegiatan pramuka dalam membentuk karakter disiplin siswa, terdapat berbagai 
metode untuk membentuk karakter disiplin yaitu penerapan reward dan punishment, perintah dan arahan secara langsung, serta pengkondisian pada setiap tindakan.

2. Impelementasi kegiatan pramuka dalam membentuk karakter disiplin siswa SD/MI telah berjalan sebagaimana yang diharapkan.

3. Kedisiplinan akan waktu sangat penting, mulai dari kedisiplinan menepati waktu.

4. Kedisiplinan terhadap diri sendiri adalah kunci dalam segala hal.

5. Kedisiplinan dalam menjaga kondisi fisik agar selalu sehat dapat dilakukan dengan cara makanan-makanan yang bergizi seimbang, istirahat yang teratur dan beolahraga secara teratur.

\section{Saran}

Atas dasar telaah, kajian dan simpulan di atas, penulis merekomendasikan hal-hal sebagai berikut:

1. Bagi sekolah agar kiranya dapat meningkatkan kegiatan-kegiatan pramuka lagi kualitas kegiatan pramuka menunjukkan bahwa kegiatan pramuka terbukti mampu memberikan kontribusi yang kuat dalam membentuk karakter disiplin.

2. Bagi siswa agar lebih giat lagi dan lebih semangat lagi dalam mengikuti kegiatan pramuka, karena kegiatan ini benar-benar memberikan manfaat yang besar terhadap diri kita.

Penulis juga berharap ada peneletian lagi tentang permasalahan ini agar enelitian ini menjadi sempurna dan menambah wawasan kita semua terhdap kegiatan pramuka.

\section{DAFTAR PUSTAKA}

Aji, A. H. (2016). Pendidikan Karakter Dalam Ekstrakurikuler Pramuka Di Smp Negeri 1 Yogyakarta. Kebijakan Pendidikan, V, $1-15$.

Moh. Imam Mukhlis. (2016). Implementasi Kegiatan Pramuka Dalam Membentuk Karakter Disiplin Siswa Anggota Gerakan Pramuka Di Sekolah Dasar Negeri Sukun 3 Malang. Skripsi.

Tofiq Muctharjo. (2013). Pembentukan Karakter Disiplin Dan Tanggung Jawab Melalui Pemahaman Dasadarma Dalam Kegiatan Ekstrakurikuler Pramuka Pada Siswa Sma Negeri 3 Wonogiri Tahun 2013. Skripsi, 1-15.
Upik Isriyanah. (2007). Kegiatan Kepramukaan Sebagai Sarana Menumbuhkan Kedisiplinan Siswa Smp N 1 Dukuhturi Kabupaten Tegal. Skripsi, 1-156. 